Jurnal Konstruksi Hukum | ISSN: 2746-5055

Vol. 2, No. 2, Mei 2021, Hal. 233-237| Tersedia online di

https://www.ejournal.warmadewa.ac.id/index.php/jukonhum

DOI: https://doi.org/10.22225/jkh.2.2.3212.233-237

\title{
PERLINDUNGAN HUKUM TERHADAP ANAK SEBAGAI PELAKU TINDAK PIDANA DARI PERSPEKTIF KEMERDEKAAN PERS
}

\author{
Kadek Mahadewi, I Wayan Rindeng, Ida Ayu Putu Widiati \\ Fakultas Hukum, Universitas Warmadewa, Denpasar - Bali, Indonesia \\ mahadewikd@gmail.com, wayanrideng1965@gmail.com,Widiatidayu@yahoo.co.id
}

\begin{abstract}
Abstrak
Perlindungan hukum terhadap anak yang berhadapan dengan hukum adalah salah satu aspek yang penting yang harus diperhatikan oleh semua pihak unruk menghindari dampak negatif yang dirasakan oleh anak apabila hakhaknya dilanggar. Metode yang digunakan penelitian hukum normatif. Pelaksanaan kemerdekaan pers dalam melakukan suatu pemberitaan belum sesuai dengan peraturan tentang perlindungan anak dan kode etik jurnalistik karena masih ditemukannya pelanggaran yang dilakukan pers dalarn pemberitaan mengenai anak sebagai pelaku tindak pidana yang identitasnya dipublikasikan baik di media cetak maupun elektronik sehingga dari pelanggaran tersebut memberikan dampak negatif baik secara fisik maupun psikologis kepada anak. Dari pelanggaran tersebut perlu adanya pertanggungjawaban dari pihak per dan sanksi yang diberikan kepada pers yang melanggar hak-hak anak diatur dalam Kitab Undang-Undang Hukum Pidana. Tujuan penelitian ini untuk mengetahui perlindungan hukum terhadap anak sebagai pelaku tindak pidana bagaimana implikasi dari kemerdekaan pers yang melanggar hak-hak anak sebagai pelaku tindak pidana.
\end{abstract}

Kata Kunci: Perlindungan Hukum, Pertanggungjawaban, Pers Terhadap Anak.

\begin{abstract}
Legal protection for children who consider the law is one important aspect that must be considered by all parties who are not responsible for the negative impact felt by children, their rights are violated. The method used is normative legal research. The implementation of press freedom in reporting is not in accordance with the regulations on child protection and journalistic code of ethics because there is still news that is carried out by the press in reporting about children as a criminal act whose identity is well publicized in print and electronic media so that it has a negative impact either physical and psychological to the child. This requires accountability from the parties and the sanctions given to the press who violate children's rights are regulated in the Criminal Code. The purpose of this study was to determine the legal protection of children as a criminal act, what are the implications of press freedom that violates children's rights as a crime.
\end{abstract}

Keywords: Legal Protection of Children, Press Accountability.

\section{PENDAHULUAN}

Indonesia adalah negara hukum, sehingga kehidupan dalam bermasyarakat, berbangsa dan bernegara harus berdasarkan pad a norma dan nilai yang ada dalam Pancasila menjadi pedoman hidup,guna menciptakan kehidupan masyarakat yang tertib dan seimbang. Dalam hal ini masyarakat memiliki kewenangan selaku subyek hukum yang berkewajiban mendapatkan perlindungan hukum atas hakhak yang dimilikinya. Menurut C.S.T Kansil, "perlindungan hukum adalah berbagai upaya yang harus diberikan aparat penegak hukum untuk memberikan rasa aman, baik secara pikiran maupun fisik dari gangguan dan berbagai ancaman dari pihak manapun" (Kansil, 1989, p. 40). Dan menurut Satjipto Raharjo, "perlindungan hukum adalah memberikan pengayoman kepada hak a asi manusia yang dirugikan orang lain dan perlindungan tersebut diberikan kepada masyarakat agar mereka dapat menikmati semua hak-hak yang diberikan oleh hukum" (Raharjo, 2000, p.53). Secara filosofi anak sebagai bagian dari generasi muda, sebagai salah satu sumber daya manusia yang merupakan potensi dan penerus cita-cita perjuangan bangsa dimasa yang akan datang, yang memiliki peran strategis serta mempunyai ciri dan sifat khusus, memerlukan pembinaan dan perlindungan yang khusus pula. (Nashriana: 2011: 76). Hak Asasi Manusia (HAM) adalah hak yang secara hakiki dimiliki oleh manusia karena martabatnya sebagai manusia yang dimilikinya sejak lahir (Suseno: 2010: 121).

Dalam pemberitaan tersebut sangat jelas dituliskan identitas anak yang bersangkutan yang meliputi nama, alamat tinggal, bahkan jenis tindak pidana yang melibatkan dirinya. Pers telah melanggar privasi anak, demikian juga telah melanggar ketentuan dalam Undang-Undang 
Perlindungan Anak. Semisal jati diri anak disebarluaskan ditunjukkan kepada masyarakat luas, akan memicu kerugian secara fisik dan psikis, lalu masa depan di bidang Pendidikan akan terancam dan mendapatkan dampak buruk dari masyarakat juga dapat menimbulkan trauma. Gosita (2004:222) yang dimaksud korban adalah mereka yang menderita jasmaniah dan rohaniah sebagai akibat tindakan orang lain yang mencari pemenuhan kepentingan diri sendiri atau orang lain yang berhubungan dengan kepentingan dan hak asasi manusia. Ada beberapa faktor penyebab yang paling mempengaruhi timbulnya kejahatan anak, yaitu: (Meliala dan Sumaryono: 1985: 31)

1) Faktor lingkungan

2) Faktor ekonomi / sosial

3) Faktor psikologis

Pelanggaran yang dilakukan oleh pers tersebut disebabkan karena adanya kekosongan norma dalam Undang-Undang Perlindungan Anak yang tidak mengatur mengenai sanksi bagi pelaku yang menyiarkan jati diri anak yang berhadapan dengan hukum. Akibatnya banyak timbul pelanggaran dari ketentuan tersebut karena tidak adanya sanksi yang dapat membuat jera pelakunya.

Dari pemaparan latar diatas maka dapat dirumuskan tujuan dari penelitian ini untuk perlindungan hukum terhadap anak sebagai pelaku tindak pidana serta implikasi dari kemerdekaan pers yang melanggar hak-hak anak sebagai pelaku tindak pidana?

\section{METODE PENELITIAN}

Jenis penelitian ini adalah jenis penelitian hukum normatif, karena penelitian dilakukan melalui penelitian kepustakaan berdasarkan bahan hukum. Metode masalah yang digunakan dalam penelitian ini merupakan metode hukum, konseprual dan kasus. Beberapa sumber hukum dipergunakan dalarn isi penelitian ini yakni hukum normatif ini yaitu bersumber bahan hukum primer, bahan hukum yairu yang terdiri dari Undang-Undang dan keputusan-kepurusan yang mengikat (Sugiyono, 2008, p. 73). Sumber bahan hukum sekunder adalah bahan hukum yang didaparkan dari tinjauan pustaka yaitu buku hukum, jurnal hukum, dan internet terkait perlindungan hukum anak sebagai pelaku tindak pidana dari perspektif kebebasan pers. Sumber bahan hukum kategori ketiga adalah bahan hukum yang diperoleh dari kamus hukum, ensiklopedia dan ilmu hukum lainnya. Teknik pengumpulan bahan hukum yang digunakan di penelitian ini penulis melakukan pendataan dan perangkuman. Melakukan penelitian kepustakaan dengan membaca, mencatat, mengutip, dan meringkas konten yang berkaitan dengan topik yang dibahas. Bahan-bahan hukum yang diperoleh keseluruhan dari kepustakaan berupa bahan-bahan hukum maupun peraturan perundang-undangan dianalisis dengan metode teknik deskripsi, sistematisasi, dan argumentasi dengan cara menyusun bahan hukum secara sistematis serta dihubungkan dengan bahan hukum yang lainnya agar mendapat keterbukaan yang sebenarnya, begitu juga sebaliknya, agar mendapat gambaran baru dengan jelas.

\section{HASIL DAN PEMBAHASAN}

\section{PerlindunganHukum Terhadap Anak Sebagai Pelaku Tindak Pidana}

Kawula muda yang hendak menyalurkan cita-cita kebangsaannya dan membawa harapan kepada generasi sebelumnya di masa depan, membutuhkan kesempatan terbesar untuk berkembang dan berkembang secara mental, fisik dan menyenangkan. Perlindungan hukum anak merupakan upaya atau aktivitas yang dilakukan oleh semua golongan masyarakat dalam berbagai situasi dan posisi serta peran, sepenuhnya mengakui pentingnya anak untuk bangsa serta negara di masa depan.

Perlindungan anak adalah seluruh tenaga untuk menciptakan situasi supaya masing-masing anak pandai menjalankan hak dan kewajibannya secara fisik, mental, dan sosial untuk mempertahankan kelangsungan hidupnya secara alami. Perlindungan anak merupakan perwujudan keadilan sosial, oleh karena itu perlindungan anak diupayakan di segala bidang kehidupan berbangsa dan sosial yang menyangkut akibat hukum baik tertulis maupun tidak tertulis. Masalah ini tidak hanya dapat diselesaikan melalui cara hukum, tetapi jug a membutuhkan solusi yang lebih luas lagi, yaitu: "Ekonomi, Masyarakat dan Budaya" (Garuda, 1986, p.22). Perlindungan hukurn anak terkait dengan beberapa hal yang perlu diperhatikan yaitu:

1. Luas lingkup perlindungan:

a. Perlindungan utarna meliputi: sandang, pangan, papan, perumahan, Pendidikan, kebersihan, dan hukum; 
b. Termasuk keadaan material dan/atau spiritual;

c. Ini juga melibatkan klasifikasi kebutuhan primer dan sekunder, yang mengarah pada pemenuhan prioritas.

2. Menjamin perlindungan:

a. Tentunya akan mendapatkan perkembangan yang tertinggi maka harus dipastikan implementasi aktivitas konservasi, dan semua bagian yang bergabung di daJam aktivitas konservasi dapat mengetahui;

b. Di sisi lain, jaminan perlindungan dituangkan dalam peraturan tertulis dalam bentuk peraturan perundang-undangan atau peraturan daerah, yang mudah dirumuskan dan dapat merata di masyarakat;

c. Peraturan harus disesuaikan dengan kondisi dan keadaan Indonesia, dan tidak boleh mengabaikan Tindakan perlindungan yang harus diambil dan ditiru oleh negara lain (Gosita, 2004, pp. 4-6).

Perlindungan anak yang dilaksanakan berdasarkan Pancasila dan prinsip dasar Undang-Undang Dasar Negara Republik Indonesia Tahun 1945 dan Konvensi Hak Anak meliputi:

a. Tanpa diskriminasi;

b. Kepentingan terbaik anak;

c. Hak untuk hidup, bertahan hidup dan berkembang; dan d. Hormati pendapat anak dalam prosedur non litigasi, aparat penegak hukum, dan perlindungan anak ilegal.

d. Litigasi Bentuk perlindungan yang terdapat daJam prosedur hukum disebut litigasi yaitu bentuk perlindungan. Dalam ruang sidang anak, identitas anak dirahasiakan, anak yang melakukan tindak pidana sebelum umur 12 (dua betas) tahun dikembalikan ke orang tua/walinya, petugas tidak boleh menggunakan pakaian kedinasan, anak wajib didampingi orang tua/wali, pekerja sosial kemasyarakatan dan penasihat hukum, dan tidak ada penahanan selama anak mendapat jaminan dari orang tua/wali.

e. Non Litigasi dilakukan melalui diversi yaitu pelimpahan penanganan kasus anak dari prosedur peradilan pidana selain prosedur peradilan pidana. Gunakan metode keadilan restoratifuntuk: menemukan solusi yang adil dan rnengembalikannya ke keadaan semula, daripada membalas.

f. Aparat Penegak Hukum

g. Aparat penegak hukum dalam hal ini meliputi hakim, jaksa, polisi yang rnelaksanakan peradilan pidana anak yang mempunyai aturan tersendiri dalam rangka perlindungan anak yang berkonflik dengan hukum.

h. Pendamping Anak Yang Berhadapan Dengan Hukum

i. Pendamping anak yang berhadapan dengan hukum berdasarkan Undang • Undang Sistem Peradilan Pidana meliputi, pembimbing kemasyarakatan, pekerja sosial profesional, tenaga kesejahteraan sosial, orang tua/wali, advokat dalam hal ini orang yang dipercaya oleh anak untuk: mendampingi selama proses peradilan pidana berlangsung.

\section{Implikasi Kemerdekaan Pers Yang Melanggar Hak-Hak Anak Sebagai}

Pelaku Tindak Pidana Etika adalah nilai dan asas yang dikonseptualisasikan sebagai pedoman tindakan yang benar tanpa merugikan keinginan orang lain. Menurut aturan hukum, semua tindakan harus berasaskan aturan hukum yang berlaku. Jurnalistik adalah kegiatan mencari informasi, menyunting informasi dan berita, serta memberikan informasi berupa kata-kata, bunyi, gambar, dan perlu untuk mengedepankan nilai - nilai moral. Karenanya, perilaku pemberitaan tidak akan merugikan hak orang lain. Demi menjaga nilai moral pers nasional, seluruh aspek pemerintahan dan jurnalis harus bekerja keras. Lndonesia menganut prinsip demokrasi yang berdasarkan Dalam demokrasi konstitusional, diciptakan kondisi sehingga kegiatan pemberitaan harus sesuai dengan peraruran perundang-undangan yang berlaku. Unruk menjaga kebebasan pers, diundangkan UndangUndang Pers sebagai dasar legalitas kebebasan yang diarur oleh Undang-Undang Dasar.

Dalam rangka melindungi kebebasan pers nasional, maka lahirlah kode etik jurnalistik yang menjadi dasar penyelenggaraan kegiatan jurnalistik di seluruh pelosok tanah air. Kode etikjurnalistik telah menjadi dasar moral dan etika profesi sebagai patokan operasional dalam membangun kepercayaan publik dan menanamkan integritas dan profesionalisme. Namun dalam penerapan Kode 
Etik Jumalistik belum sesuai karena masih ditemukannya pelanggaran yang dilakukan oleh pers dalam melakukan pemberitaan termasuk media cetak dan media elektronik, salah satunya pemberitaan anak sebagai pelaku tindak pidana yang jati dirinya disebarluaskan. Sehingga pers dalam hal ini sudah melanggar dari ketentuan Kode Etik Jurnalistik tersebut. Maka dari pelanggaran tersebut perlu diadakannya evaluasi yang dilakukan terhadap kinerja-kinerja pers maupun media massa agar kedepannya lebih memperhatikan hak-hak anak yang seharusnya tidak boleh dilanggar oleh siapapun demi kelangsungan hidupnya.

Dari pelanggaran pempublikasian identitas anak sebagai pelaku tindak pidana yang dilakukan oleh pers memberikan dampak yang besar bagi perkembangan anak kedepannya baik secara fisik maupun psikologisnya. Dampak yang dirasakan akibat pelanggaran yang dilakukan pers terhadap anak yang berhadapan dengan hukum dengan mempublikasikan identitasnya yaitu stigma negatif, ditolak di lingkungan tempat tinggalnya, sulit mengembangkan diri, dikeluarkan dari sekolah. Pada pelanggaran yang terjadi yang dilakukan oleh oknum pers dalam melakukan suatu pemberitaan di media cetak maupun elektronik yang berhubungan dengan anak sangat perlu untuk lebih mempertimbangkan apakah perbuatan yang dilakukan dalam suatu pemberitaan akan memberikan atau menimbulkan dampak bagi korban terutama mengenai anak, sebab anak dalam tahap pertumbuhan dan perkembangan dimana pada masa-rnasa itu anak mempunyai karakter yang belum stabil seperti orang dewasa pada umumnya dan akan mempengaruhi jiwa psikis anak dalam melakukan aktivitasnya baik di area sekolah maupun di area tempat tinggalnya.

Untuk bisa dihukum memburuhkan kondisi pertanggungjawaban pidana. Dalam konteks hukum pidana, unruk menenrukan apakah seseorang yang melanggar hukum akan dijatuhi sanksi pidana berdasarkan isi ancaman, sebagian besar tergantung pada apakah orang tersebut telah melakukan tindak pidana (Usfa,2004, p. 73). Moeljatno dalam bukunya berjudul Asas-Asas Hukum Pidana tidak memberikan definisi yang nyata mengenai pertanggungjawaban pidana. Namun dapat dimengerti melalui penjelasan yang diberikan tanggung jawab pidana tidak cukup untuk melakukan tindak pidana saja. Selain iru, harus ada mentalitas yang salah atau patut dicela (Moeljatno, 2002, p. 57). Tanpa ada kesalahan dalam perbuatan maka seseorang tidak dapat dipertanggungjawabkan secara pidana. Begitu pula dengan tindak pidana yang dilaksanakan oleh pers. Untuk dapat dipidana diperlukan syarat adanya pertanggungjawaban pidana. Oleh karena iru, oknum pers yang melakukan pemberitaan mengenai kejahatan yang dilakukan anak dengan mempublikasikan identitasnya dapat dibebankan pertanggungjawaban pidana atas perlakuan salah yang telah diperbuat.

\section{SIMPULAN DAN SARAN}

\section{Simpulan}

Bersumber pada pembahasan yang Penulis telah paparkan pada bab-bab diatas terdapat pokok permasalahan, maka dapat ditarik simpulan sebagai berikut:

I. Perlindungan hukum terhadap anak merupakan perlindungan bagi semua anak tanpa kecuali, termasuk mereka yang melanggar hukum, seperti mereka yang melakukan kejahatan. Tujuannya adalah untuk mewujudkan situasi bagi anak tersebut untuk menjalankan hak dan kewajibannya secara wajar, lahir batin, dan sosial, serta mendorong tumbuh kembang anak. Semua pihak berkewajiban untuk lebih memperhatikan privasi anak serta hak-hak yang dimiliki supaya anak dapat menikmati keseluruhan dari hak yang telah diberikan hukum.

2. Implikasi dari kemerdekaan pers yang melanggar hak-hak anak sebagai pelaku tindak pidana dengan mempublikasikan identitas anak tenru anak akan mendapatkan stigma negatif dari masyarakat, ditolak di lingkungan tempat tinggalnya, sulit mengembangkan diri dan sulit mendapatkan pekerjaan, serta anak dikeluarkan dari sekolah dan tidak diterima di sekolah rnanapun. Dari pelanggaran yang dilakukan oleh pers perlu adanya pertanggungjawaban atas perbuatan pers yang melanggar hak-hak anak dengan memberikan sanksi pidana untuk memberikan efek jera terhadap pelaku pelanggaran. Pertanggungjawaban dalam hal ini adalah penulis, penerbit, pencetak dan pengedar.

\section{Saran}

Bersumber pada uraian pembahasan yang Penulis paparkan, saran yang perlu diberikan adalah:

a. Kepada orang tua agar lebih memberikan perhatian khusus dan edukasi kepada anak tentang hal mana yang semestinya dilakukan dan tidak boleh dilakukan serta perbuatan yang baik dan tidak 
baik dengan memberikan penjelasan dengan baik agar anak mampu memahami dan mengerti apa yang diperbolehkan dan tidak diperbolehkan dilakukan dalam masa turnbuh kembangnya.

b. Pers dalam melakukan suatu pemberitaan terutama tentang anak yang melanggar hukum adalah anak yang melakukan kejahatan, dengan mempublikasikan identitasnya lebih memperhatikan dan mengutamakan hak-hak anak. Karena dari pemberitaan yang dilakukan oleh pers dengan mempublikasikan identitas anak yang berkonflik dengan hukum anak akan mendapatkan stigma negatif yang akan menghambat fungsi sosialnya dalam hidup bermasyarakat. Sena pers diharapkan lebih memahami mengenai peraturan hukum serta menjunjung tinggi kode etik jurnalistik yang bebas, bertanggung jawab dan profesional unruk menyajikan berita bermutu kepada masyarakat tanpa adanya pelanggaran yang dilakukan dari suatu penyebarluasan di media tertulis maupun internet.

c. Kepada pemerintah bersama DPR agar melakukan revisi terhadap Undang• mengenai perlindungan anak, agar adanya pengaturan mengenai sanksi bagi pelaku pelanggaran yang mempublikasikan identitas anak sebagai pelaku tindak pidana dengan tegas danjelas.

\section{DAFTAR PUSTAKA}

Kansil, C. S. (1989). Pengantar ilmu hukum dan tata hukum Indonesia. Balai Pustaka, Jakarta.

Garuda, A. H. (1986). Prospek Perlindungan Anak, Perlindungan Hak-Hak. Rajawali

Gosita, A. (2004). Masalah Perlindungan Anak. Akademi Pressindo, Jakarta.

Meliala, A. S. dan E. S. (1985). Kejahatan anak suatu tinjauan dari psikologi dan hukum. Liberty, Yogyakarta.

Moeljatno. (2002). Asas-asas hukum pidana. Rineka Cipta, Jakarta.

Nashriana. (2011). Perlindungan Hukum Pidana Bagi Anak di Indonesia. PT. Raja Grafindo, Jakarta.Rahardjo, S. (2000). Ilmu Hukum. Citra Aditya Bakti, Bandung.

Sugiyono. (2008). Metode Penelitian Kuantitatif, Kualitatif dan R\&D. Alfabeta, Bandung.

Suseno, F. M. (1994). Politik: Prinsipprinsip Moral Dasar Kenegaraan Modern. Gramedia Pustaka Utama, Jakarta.

Usfa, A. F. (2004). Pengantar Hukum Pidana. UMM, Malang. 